\title{
Internet Literature in Arabic: A Case Study of Arabic Short Stories in An-Naba Newspaper, Iraq
}

\author{
Gita Amanda Alfitria, Maman Lesmana \\ Faculty of Humanities, Universitas Indonesia
}

\begin{abstract}
This research discussed about how the forms and content of Arabic short stories on An-naba Arabic newspaper. The purpose of this research to explain form and content and differentiate the short stories out of internet and to short stories which published in print and knowing the characteristic of online literature especially Arabic short stories which are published in An-naba Arabic newspaper.This research uses descriptive qualitative research methods, literature study and content analysis methods and using hypertext theory by Theodore $H$. Nelson. The results of this research that form of these arabic short stories similar to short stories which published in print while the content of these stories shortest than stories published in print and the sequel of this stories in the Arabic short stories looked like continuing
\end{abstract}

Keyword: Online literature, Arabic short stories, An-naba newspaper, Iraq

\section{INTRODUCTION}

$\mathrm{T}$ alking about internet literature is certainly inseparable from advances in the field of technology. Quoted from Lenze (2012) the term internet literature emerged in 1960 in Europe and the US, then followed by hypertext literature. Meanwhile, there is another opinion according to Cogburn in cyberspace and social media (Acharya, 2016) that the term internet literature originated from the term cyberspace which appeared around 1980 in science fiction, then in the 1990s in popular culture. Initially the term cyberspace referred to all online spaces that use the internet, through fixed and mobile communication networks including the World Wide Web and all popular social media and other applications that use these devices. Furthermore, people around the world use cyberspace for social, political and economic purposes including in disseminating literary works

Jamal D. Rahman (in Wicaksono, 2017) argues that distributing literature in a medium, where literary works are distributed, can be ascertained that each media determines the form and tendency of the literary work itself. So that the emergence of terms such as internet literature, magazines and newspapers. However, the term is more of an "identity politics" in the discussion of the literary world. The term cannot be said permanently except only as a differentiator. So that these terms are more to the judgment of the reader. Thus, a good literary work depends on the judgment of the reader of the literary work itself, not carefully drawn conclusions or used as comparisons.
In the Arab region, around the mid-1990s, people and governments began to access the internet. The first Arab country to allow its citizens to access the internet was Kuwait in 1995. In early March 1997 a number of representatives from the Gulf Cooperation Council met to discuss wider access to the internet. Entering the 2000s the internet was growing rapidly in the Arab region. Some well-known writers from the Middle East such as Samuel Shimon, Tukri AlDhakil, Haifa Bitar and Shakir Nouri say that the existence of the internet for the world of Arabic literature outweighs the disadvantages. According to some of these writers in the past, Arabic writings were only distributed in Arab countries, but the emergence of the internet has made various world countries other than Arab countries able to access them (Yusuf, 2013).

The development of the internet in the Arab region has sprung up many websites dedicated to publishing Arabic literary works. As in 2000 the Kuwaiti writer Karim Al-Haza and the two brothers Muhammad and Salah Al-Nabhan the founders of ufuq magazine living in Canada. They finally digitized the magazine by publishing a literary culture journal online through the ufuq website every month. Then in 2003 the young Kuwaiti writer Hayat al-Yaqut founded the first Arabic online publication to accommodate young writers and give them the opportunity to publish his work for free on a platform that has a regular readership and accepts free editing. However, authors wishing to publish on this website must follow a series of criteria including that they must write in Modern Standard Arabic and their work must not violate any code of ethics or law (Pepe, 2019)

From these examples, many literary works such as poetry, novels, short stories are found on the internet, both in personal blogs, online forums, online newspapers, websites and applications. One of them as contained in the online newspaper An-Naba Iraq. The newspaper contains news and information from the Arab and international world as well as literature. The choice of An-Naba newspaper to be researched was because the author saw that from the many online newspapers in Iraq, this newspaper has a cultural and informational rubric, which includes a rubric on literature. In this literature section there are differences between poetry, opinions about literary works and short stories. In this study, the authors took the corpus of short story data in the online newspaper An-Naba Iraq because in this section the number of short stories contained was more than poetry. From this 
explanation, there are interesting problems in this study, namely how the form and content of the short story are and what are the characteristics of internet literature, especially the short stories contained in the newspaper. The purpose of this study is to explain the form and content of Arabic short stories in the Iraqi An-Naba online newspaper and to find out the characteristics of internet literature, especially regarding the short stories contained in the newspaper.

\section{LITERATURE REVIEW}

In this study, the literature review section contains previous research. There are several studies that have been carried out using internet literature as the object of study. The first research is a thesis entitled "Telling Stories online in the Gulf Prolegomena to The Study of an Emerging from Arabic Literary Expression" by NeleLenze. This thesis discusses short stories, short literary texts published on blogs, online forums and online publishing house Nashiri. The focus of this research on internet literature lies in three main areas, namely blogs, online forums and online publishing by Nashiri because these three things are the most frequently used by online writers in the region and have a long tradition. The method used is critical discourse analysis or critical discourse analysis. According to Lenze, this method is mostly used for interdisciplinary and researching language as social criticism, but he chose this method because it is very important in referring to separate discourses that form public reflection on one subject, in the use of literary texts, this method is needed to analyze selected discourse in various stories.

Elnaili also conducted research on Arabic short stories. In her article, "Female Protagonist in Libyan Short Story Post the Arab Spring: A Critical Discourse Analysis",she examines how Libyan women are represented in literary texts through female protagonists after the Arab Spring. Her research applies critical discourse analysis to critically analyze how gender stereotypes are reproduced through the use of language in sociopolitical contexts. The data used are several short stories from Libya written by male and female authors, providing analytical reading of women's representatives after the Libyan uprising. In conclusion, the article states that these short stories do not reflect the contribution of the feminine in the Libyan revolution. They mostly channel the social injustices that are practiced against women in society. Women are depicted as weak, marginalized, and deprived of their simple rights. Libyan writers need to rethink their approach to women's representation by discussing negatives and positives in parallel.

\section{Research Methods and Theoretical Framework}

In this study using several methods. The first method is a qualitative method. The qualitative method is a method for analyzing narratives in the form of words, text, illustrations, videos and other non-numeric formats (Lesmana, 2019). This research procedure produces descriptive data in the form of written and oral words which are then interpreted (Anggito; Setiawan, 2018). Therefore this type of research requires in- depth interpretation and analytical thinking about what is being studied (Lesmana, 2019). The source of the research data analyzed comes from the internet, namely qualitative data in the form of a collection of short stories in the Iraqi AnNaba newspaper starting from the August 2015 to August 2020 edition. Meanwhile, the method used in collecting reference sources is in the form of literature studies in books, journals and articles. . This study also uses the content analysis method, which is one of the main methods used in communication science, but along with its development this method is also widely used in other studies because this method is to study and draw a conclusion from a phenomenon by utilizing documents (Eriyanto, 2008). 2015). In relation to this research, the author uses this method because the short stories to be studied are contained in online newspapers. Through content analysis, the author can study the description of the contents, characteristics, messages and developments contained in these short stories. After the data is processed and interpreted, then analyze it according to the predetermined theory. The theory used in this research is the hypertext theory introduced by Theodore H. Nelson.

In a book entitled Hypertext 3.0: Critical Theory and New Media in an Era of Globalization by George P. Landow the concept of hypertext was first put forward by Theodore $\mathrm{H}$. Nelson in 1960 which refers to the form of electronic text. According to him, electronic text is a text that is offered through a computer screen where various text options are available for the readers. Of course in this case the influence of technology and the internet plays an important role in the development of hypertext. While Roland Barthes describes the term hypertext, namely "text composed of blocks of words (or images) linked electronically by multi paths, chains, or trails in open ended, perpetually unfinished textuality described by the terms link, mode, network, web and path" ( Text consisting of blocks of words (or images) linked electronically by multiple paths, chains or without a planned ending, unfinished textuality described by the terms link, mode, network, web or path).

However, this concept was actually used much earlier in a speech on the development of hypertext by Ralph Waldo Emerson in 1837 and by Vannevar Bush an American scientist who wrote an essay entitled "As We May Think" published in the July 1945 issue of the Atlantic Monthly. In the essay, it is about how a personal device is turned into a mechanical device and has speed and flexibility that exceeds limits and can distribute the entire library of human knowledge. The ideas proposed by Bush illustrate the basics of hypertext theory which indirectly describes the internet. Then the idea can be assumed that humans need a computer or personal device that is used as a larger space or storage device to collect relevant knowledge and information that may have previously been stored in our minds.

In 1991, there was a major change in the use of hypertext with the invention and development of the World Wide Wibe which connected stored data from around the world. At first 
hypertext was used for factual data and was limited to scientific, academic, military and government information and institutional purposes, but in its short history hypertext developed in form and function that exceeded its original purpose. According to Jakob Nielsen in the use of hypertext theory, there are two things that must be understood in using this theory, the first through a scientific approach that shows the technical and medical aspects of new media and the second through a post-structuralist approach that explains from the point of view of a literary scholar by emphasizing function and potential theoretically.

Of course, there are differences between electronic text and conventional text. The arrangement of electronic text is not similar to conventional text, each bit of information is related to other bits of information. In addition, this system also shows certain structural possibilities for the structure of the text itself. Academics confirm these truths by looking at the ability in hypertext for the theories and ideas they propose. The development of hypertext makes it possible for writers and academics to have a new perspective. Although there are opposition to this theory, George P Landow is one of those who support this theory that this theory has a relationship with previous theories.

According to him, there are similarities and interesting things between hypertext theory and critical theory or literary and non-literary texts. The two are interrelated. Critical theory provides an idea while hypertext theory examines critical theories, especially those related to textuality, narrative and the role of writers and readers. By using hypertext theory, critical theorists have laboratory space to test their ideas. The most important thing is that the experience of reading through hypertext greatly clarifies the ideas of critical theory. Related to the phenomenon of internet literature, hypertext theory can be used as a reference for scholars and students who are reader-centered to read a text because they can choose the text or information they want and use it in a large network such as the internet. There is quick and easy access to various sources, electronic texts and other materials that are very helpful for users.

\section{DISCUSSION}

These short stories are divided into two sections. The first discussion about the form of Arabic short stories in the Iraqi An-Naba newspaper on the internet, namely plot, setting, characters and characterizations. The second is about the content of the short story which consists of a theme and a mandate. The short stories that will be studied are 11 Arabic short stories from 23 short stories in the August 2015 to August 2020 editions. The following is the web view of the Iraqi An-Naba online newspaper.

\section{Plot}

Plot is one of the intrinsic elements in literary works such as novels and short stories. The definition of plot according to Forster is a series of story events that focuses on cause-and- effect relationships. The next opinion by Stanton argues that the plot is a story that explains the sequence of events that are connected by cause and effect that each event in the story occurs because of the cause of previous events. (In Nurgiyantoro, 1995). The plot in short stories usually doesn't look too flashy because of the shortness of the story. To understand the plot in the short story, it can be seen a series of events from a story that starts from the beginning to the end. There are several types of forward grooves, reverse grooves and mixed grooves. The collection of Arabic short stories contained in the online newspaper An-Naba as a whole has a storyline like other short stories. One of the short stories written by Asma Muhammad Mustafa entitled (The Pigeon That Doesn't Come Back) (https://annabaa.org/arabic/literature/20860)

This short story tells of a husband and wife from Baghdad, where the wife that morning saw two pigeons landed on her balcony and gave them food and drink. At that moment the woman overshadowed the incident when they visited their nephew in prison. The husband is still questioning why Iraqi travel authorities sent his sister and husband to Iran and detained their sons Ali and Mohsen. Their last meeting was when Ali and Mohsen told their uncle and wife that they had received military uniforms from the prison administration. As written in the paragraph below:

She often relied on this sign of fate, on what he saw in his dreams, that they came back like doves, going and coming back.

The woman felt that every arrival of a dove on the balcony of her house was a sign of her nephew's destiny to come back like a dove that left and would return.

In his imagination, he several times saw in his dreams two young men coming without knowing where they came from. He also saw in his last dream Ali and Mohsen were in the desert among a group of youths wearing military uniforms. They hoped for a miracle to get out of prison. Like in this paragraph

He always saw in his dreams, before the tank entered, symbols and events foreshadowing the return of two young men from the unknown. But on the night when the tanks rolled in their path, he saw in his dream that Ali and Mohsen were standing among a group of youths in the desert in their military uniforms.

The plot in this short story uses a backwards plot because it can be seen from the beginning that the story only tells the fantasy of a woman who she saw in her dream, also remembering the last time she met Ali and Mohsen. At the end of this short story as if there is a continuation of the next story. However, at the end of this short story, it is still in the same situation and circumstances. The woman is still on the balcony of her house. As in the paragraph below

In the morning his heart was shaken, when he saw the two pigeons after drinking water from the plate and full of grain, 
rising from the balcony of his house they flew randomly and fell out of his sight that morning.

\section{Setting}

Setting refers to the sense of place, time relationship and the social environment in which an event is told. Stanton (in Nurgiyantoro, 1995) classifies the setting as a fact of the story, including the characters and plot. All three are real and directly form the story. The setting itself has three main elements, namely time, place and social. These three elements offer their respective problems, but also have a relationship and influence each other. In the collection of Arabic short stories in the online newspaper An-Naba, almost all short stories contain the main elements of the story setting, whether it is time, place or social setting.

Setting of place indicates the location of an event or events in a work of fiction. In its use, the setting of a place may mention names and initials or perhaps a certain location without a clear name or it may only explain the characteristics of a particular location. For example, in a short story entitled (Abandoned) (https://annabaa.org/arabic/literature/20213) written by ZainabFakhry. This short story tells the story of a mother who tries to escape from her country, which is an Arab country and seeks a safe place of refuge for her two children. The condition of his country at that time was very chaotic and there was a war. As in several sentences in the short story below.

With one foot in the burning sand and the other swollen... I continued my journey with my two daughters....

Continuing the sentence in another paragraph

This desert does not help meet and cover my life needs

Days passed before they even thought of transferring us to another camp.

It can be seen from the paragraphs of this short story that the background of a place that is characteristic of the Arab region, namely the desert, also mentions the setting of another place, a camp which is characteristic of a country that is being hit by chaos and war.

Another short story entitled كتاب الحياة (Book of Life) (https://annabaa.org/arabic/literature/14393) written by Abdul Amir Al-Majar mentions one of the cities in Iraq, namely Al Majer Al Kabir, as mentioned in the sentence in short stories

I'm a teacher. I spent more than ten years in service at a school at the end of a remote village. I was asked to go there every day, about an hour by car. On the way every day I get enlightened, even though I have to penetrate the narrow streets of my town Al Kabeerah, passing a kind of reeds that are relatively far from the city center to the village where my school teaches.

The use of place settings that highlight the Arab region, especially Iraq in the collection of short stories of the An-
Naba newspaper as a whole is relatively small. The use of place settings that show the name of the city or certain initials is also rarely found. Most of the setting in which this short story only mentions certain locations without clear names such as at school, at home, in the room, on the street without mentioning the clear name and characteristics of a particular area.

The setting of time in fiction usually relates to the problem of "when" the event occurred. The problem of "when" can relate to factual time, time that relates to or is connected with past events. The problem of time in fiction according to Genette (in Nurgiyantoro, 1995) is defined as double. The first time leading to the writing of the story. The second shows the time and order in which the event occurred. The use of time setting is often associated with the length of time a story takes. However, in several other works of fiction, the use of time setting is not shown clearly, it seems vague or even not shown at all (Nurgiyantoro, 1995). For example in the short story entitled (Aroma Ayah) (https://annabaa.org/arabic/literature/17794) written by Ali HuseinObaid. Seen in the excerpt of the short story below, it shows that there is a time setting, namely in the morning

In the morning the sun shines beautifully and its light enters through the window into a spacious room that is pleasing to the soul. The boy finished putting on his clothes and ate the breakfast that his mother had prepared, took his school bag and stepped out the door

Overall, the collection of short stories in the An-Naba newspaper shows the use of a time setting, either indicating the time when the events of the short story occurred or the time sequence of the events in the short story. Although it is not clearly stated, such as the day, date and year as a whole, there is mention of the use of the time setting.

The social setting refers to the various problems of a person's social life in a place that is told in the work of fiction. Social background can be in the form of customs, habits of life, beliefs, views of life, traditions of beliefs and how a person behaves and thinks. The things that have been mentioned previously are certainly related to environmental conditions and social status. The social setting is the most dominant element in determining the setting because the social setting determines the setting of place and time setting to characterize a story or vice versa. For example, in a short story entitled (Heritage) (https://annabaa.org/arabic/literature/13985) written by Abdul Amir Al-Majar. In this short story it is mentioned in the sentence below

My father told me, quoting from my grandfather who told him the story, and he asked my father to pass it on to us, we are his children. He told of a tall thin man wearing Western clothes, He dressed in a different style to this country,

The social setting of the short story shows that there is a hereditary tradition regarding inheritance. The grandfather 
told me that there was a man who was looking for a settlement of an inheritance case that had not been resolved by his father and grandfather. The inheritance was not explained in what form and several courts were also unable to resolve the case due to the lack of files and the ambiguity of the inheritance so that it did not find a bright spot. It ends with a sentence in the short story as follows:

No one paid any attention to the tall, skinny man as he disappeared with a collection of case papers that had been secretly settled for a long time, but the story of his out-ofcourt settlement has been the subject of conflict between bloggers and historians, and a resolution remains unsolved.

Another short story entitled السور (Fence) (https://annabaa.org/arabic/literature/14419) was written by Abdul Amir Al-Majer. This short story is about a family. In the short story, there are many social backgrounds in the form of life habits. One of the social backgrounds that arises is the habit of rushing in the morning as in the example of the following sentence

Before I fall asleep, I suffer from insomnia, I usually rush in the morning to leave, but the force of the night crushes me like a rag between the folds of the bed..Our house is full of women, they gather together, until I feel that I see a black mass that fell from the sky... when I came, stood up and saw my face.....

In the collection of An-Naba's short stories, most of the social settings are in accordance with the themes that have been mentioned by some writers related to life such as human values, traditions in the family, views of life.

\section{Characters and Characterizations}

Character refers to the person or actor in the story. In this case, of course, there is something to do with the character traits of the actors in the story, which refers more to the personal qualities of a character. Jones argues (in Nurgiyantoro, 1995) that characterization is a clear description of someone who appears in the story. Abrams (in Nurgiyantoro, 1995) explains that story characters are people who appear in a narrative or drama work. Characters are also related to character so that it is not uncommon for characters to directly indicate to the readers about their character. In addition to being associated with character, the author in a novel or short story character usually writes the name of the character in the story. However, the term characterization is more appropriate because it includes characters and character traits. The collection of short stories in the An-Naba newspaper mostly displays characterizations in the story, but in this collection of short stories it is more dominant to display story characters using pronouns such as I, we, they, he, one. For example, in a short story entitled النافذة (Jendela) (https://annabaa.org/arabic/literature/21944) written by Ali Hussein Obaid. From the beginning, this short story only mentions a character with the word "I" as a wife waiting for her husband to come from the war. The character of the wife is also described as a wife who is strong and strong and remembers her husband a soldier who fought for his country. Seen in the dialogue of short story quotes

He wore battle clothes, adorned with belts and armor, put a gun on his shoulder, smelling from him the scent of the dust that had been redeemed, my homeland, my refuge and the refuge of my children, He asked me with words like a soldier ready to go to war:

"Don't forget our sweet memories, take care of the children with your love"

I looked at him as tears rolled down my eyes and down my cheeks.

"As I promised last time when I went to war, I will come back this time too, don't worry, your crying hurts me."

The husband character depicted in the short story can be seen from the author's exposure and dialogue with his wife, namely having a firm character, being brave as a soldier but gentle as a husband.

Another short story entitled فقاعة سوداء (Black Bubbles) (https://annabaa.org/arabic/literature/19798) was written by Abdul Aziz Al-zayed. This short story tells of a man who is depressed during his crisis. Most of the characters in this short story only mention the main character "he" which is a man. The characterization of the character itself is described through the exposure of the author. His character looks depressed because of the situation he is in. As in the following paragraphs.

He was living in a sudden depressed state, his life was generally good, so why was he suffering from this distress and boredom?! Is there a reason and a path leading to this bubble that is urging it out and wanting to suffocate it?! Circumstances may interfere with life, but why not walk away from the tribulation that befell him?! He had been through similar situations before, but they disappeared over time as the influence wore off, and the impact would lessen with each passing day.

Overall, the characterizations in this collection of short stories are described through the author's own exposure, but there are several short stories that describe the characterizations through dialogue between characters.

\section{Theme}

The theme becomes the basis of a story which will be developed by the author so that the theme can animate all parts of the story. Stanton argues (in Nurgiyantoro, 1995) that the theme is the meaning of a story that outlines the elements of the story in a simple way. He also stated that the theme is more or less the same as the main idea and purpose. In general, the theme raises the issue of life. Such as matters relating to matters of love, family, justice, war, poverty and so on. It can also be related to the experience of the author 
himself, both individual and social. Themes are divided into traditional themes and non-traditional themes. Traditional themes are based on attitudes and ways of thinking and acting that adhere to norms and customs. According to Nurgiyantoro (1995) traditional themes are universal, usually taking up stories that have been used for a long time, such as themes related to life. For example, in one of the short stories entitled (Children of Traffic Lights) https://annabaa.org/arabic/literature/19193) written by Asma Muhammad Mustafa. This short story raises the theme of poverty. As in the following short excerpt.

Every day, I used to clean the front windows of luxury cars that passed through this traffic junction, and saw the handsome boy sitting in the front seat next to the charming driver.

The explanation above is the view of the traffic light boy character. While in the sentence below from the side of a rich boy.

Then quote another paragraph:

Every day, I used to pass this intersection, and I saw this pale boy cleaning the windshield, and my father pulling out a thousand dinars from his pocket, sometimes more for the boy before the traffic police signaled us to leave after the lights. traffic has been broken for a long time.

The traffic light boy used to withstand the heat of the sun and rain. No one asked him.. What does he want? He himself asked passersby in their luxury cars: Does anyone want a newspaper..? Do you want me to clean the car for you?

Poverty in this short story can be seen from the gap between the rich and the poor as illustrated by the character of a small boy who survives by selling newspapers and cleaning car windows every day at the intersection of traffic lights with the boy in the car.

Furthermore, non-traditional themes are the opposite of traditional themes. This theme may not meet the reader's expectations, go against the grain, surprise, annoy and disappoint even various other affective reactions (Wicaksono, 2017). For example, in a short story entitled موتُ الضعفاء (A gloomy death) (https://annabaa.org/arabic/literature/18329) written by Ali Hussein Obaid. This short story tells of a girl missing and the exact cause of her death is not known. The mother feels that there is no justice from the death of her daughter, but there is information circulating from local residents who believe that her daughter drowned in the river, but there are also saying that her daughter was killed by the village's old boy. The injustice in this short story is seen because there is no one who helped Maryam when she drowned in the river, even those closest to her.

Hours passed without finding anything to indicate that the girl had drowned in the river and the sun was slowly setting, while the mother began to weep for her daughter, her cries and voices sounding intermittent because she had not found her daughter in the river this afternoon, and there were no residents. villagers who saw him when he drowned and never confirmed it.

Explanation in the next short story:

Maryam - she didn't drown and everything was like a deliberate hoax or rumor broadcast by the son of an old country man - Jaber

But in fact, Maryam has passed away, in the following quote:

I saw (his screams) the blood shed in his mouth, and I heard from his frozen mouth open calling out to me as he was in the depths of the water and drowning him, I saw everything, his sorrow, his screams, and his broken cries... He was long gone, and now I couldn't do anything, I didn't do anything for Maryam in her life.

The themes of this short story collection mostly use traditional themes as previously mentioned, but there are also several short stories that have non-traditional themes.

Message

Mandate is advice or moral message that is shown to readers of literary works that are deliberately made by the author. The message in a story can be conveyed implicitly or explicitly. Implicitly as shown in the behavior of characters and dialogue between characters. While explicitly, moral messages are usually conveyed through suggestions, advice, warnings, prohibitions or suggestions related to the theme in the story. (Satinem, 2019). The mandate usually relates to the noble qualities of humanity, fighting for universal human rights and dignity. The mandate in literary works is more directed to human nature, not to laws made which are then judged by humans themselves. But the problems of human life are distinguished in several problems, namely the relationship between humans and themselves, human relationships with other humans in the social environment, the natural environment and the relationship between humans and their God. For example in the short story entitled بائعة العلكة (Chewing Gum Seller) (https://annabaa.org/arabic/literature/18737) written by AsmaMuhammad Mustafa. This short story tells about a woman's guilt because the previous day the woman only gave him some money without helping the child. The next day he saw the girl lying on the road with her clothes mixed with mud, the chewing gum that she sold was scattered. As in the following short story quote

When she got to the turn of the road, the girl was completely wet and lying there, her black clothes mixed with the road mud, while her eyes were completely blackened, and her bubble gum box was completely crushed and the contents were scattered about.. and people were scattered. around him, feeling pity and remorse as they dragged him to the sidewalk.. and wondering why his mouth was smiling. The remnants of candy stuck to him.. I couldn't help it, I cried and ran from the 
place to my car... My blue shirt lay in the front seat, dewy and with candy specks on it.. and the sound in range repeats... Thank you brother

It can be seen from the quote from the short story that the mandate in this short story is conveyed indirectly through behavior or events that occur in the character before the story ends. The message that can be taken from this short story, the slightest kindness and in any form will always be remembered.

Another example of an implicit short story message is the short story entitled قبل رحيل الورد..... قبل (Before the departure of Mawar) (https://annabaa.org/arabic/literature/3066) written by Dr.Muhammad Muslim al-Husseini. This short story tells of a mother who writes a letter and tells about her husband whom she loves very much. Until finally her husband died. In the letter there is a moral message that is conveyed, the following is an excerpt from the short story:

One day if you wake up from your sleep and you will never see him again....you only find memories..... and you will call him and say to him: Take what you want and give me some close time with you.... love ... togetherness ....

The message from the short story that can be taken is to cherish the time with your loved ones because one day when they leave, we can only remember memories with them. Overall, the message in this collection of short stories is conveyed indirectly, either in the behavior of the characters or the events that occur in the characters of the story.

\section{CONCLUSION}

Based on the analysis that the author has done on the collection of short stories in the Iraqi An-Naba newspaper on the internet, the form of short stories that discuss characters and characterizations in general is not much different from short stories outside the internet. However, there is something that slightly distinguishes the plot of short stories outside the internet. In this collection of short stories, the story in this short story looks as if there is still a continuation of the story. Most of these grooves also use flashback grooves or flashback grooves (backwards). If you look at the contents of this short story, it is much shorter and simpler than short stories in general, especially short stories published in the form of printed books. The collection of short stories in the online newspaper An-Naba can be said to be included in short short stories with most of the themes in this short story about life experiences.

While Arabic short stories were published and disseminated in printed books before the existence of the internet, the form and content of these short stories were mostly classified as ordinary short stories or long short stories. Arabic short stories published outside the internet also do not mention in writing the theme used, the author usually describes it indirectly. In addition, short stories published in books are usually only written by an author and then collected and published in one book title.

The short stories contained in the online newspaper An-Naba are a collection of which are published on the internet so that they can be categorized as internet literature because internet media are used in disseminating literary works. The characteristics of internet literature include a literary work that will be published on the internet for the writers themselves, including easy because it does not require a strict selection of manuscripts as in literary works published through books, magazines or newspapers in printed form. There is no long or short limit in writing literary works. In addition, it is easy in terms of criticism of literary works because it is easily accessible by anyone so that readers can directly assess and discuss the literary work. However, literary works published on the internet also have shortcomings in terms of writing editing and irregular sentence structure so that the form and content of these short stories looks different from short stories published in printed books.

\section{REFERENCES}

[1] Nurgiyantoro, Burhan. (1995). TeoriPengkajianFiksi. Yogyakarta. Gajah Mada University Press.

[2] Landouw, George. P. (2006). Hypertext 3.0 Critical Theory and New Media in Era of Globalization. USA: John Hopkins University Press.

[3] Sanz, Amelia; Romero Dolores. (2007). Literatures in the Digital Era: Theory and Praxis. UK: (LEETHI Group) Cambridge Scholars Publishing.

[4] Siswanto, Wahyudi. (2008). PengantarTeori Sastra. Jakarta: Grasindo

[5] Lahlali, El Musthapa. (2011). Contemporary Arab Broadcast Media. Edinburgh: Edinburg University Press

[6] Lewis, Bernard. (2011). The End of Modern History in The Middle East. California: Hoover Stanford press.

[7] Mellor, Noha Nabil Dajani, et all. (2011). Arab Media: Globalization and Emerging Media Industries. Cambridge: Polity Press.

[8] Antilan, Purba. (2011). Pengantarllmu Sastra. Medan: USU Press.

[9] Gunter, Barier\& Dickinson, Roger. (2013). News Media in Arab World. A study of 10 Arab and Muslim World. United Kingdom: Bloomsbury Publishing

[10] Bustam, Betty Mauli Rosa dkk. (2015). Sejarah Sastra Arab dariBerbagaiPerskpektif. Yogyakarta: Deepublish.

[11] Elnaili, Safa, (2018), Female Protagonist in Libyan Short Story Post the Arab Spring: A Critical Discourse Analysis, in International Journal of Language and Linguistics 5 (2), pp.10-15.

[12] Eriyanto. (2015). Analisis Isi: PengantarMetodologiUntukPenelitianIlmuKomunikasidanIlmuIlmuSosialLainnya. Jakarta: Prenadamedia Group.

[13] Nasrullah, Rulli. (2016). TeoridanRiset Media Siber. Jakarta: Prenadamedia Group.

[14] Wicaksono, Andri. (2017). PengkajianProsaFiksi (EdisiRevisi). Yogyakarta: Garudhawaca.

[15] Pratama, BayuIndra. (2017). EtnografiDunia Maya Internet. Malang: UB Press.

[16] Sutrisna. (2018). PengantarTeori Sastra. Yogyakarta: Elmatera

[17] Anggito, Albi; Setiawan, Johan. (2018). MetodePenelitianKualitatif. Sukabumi: CV Jejak.

[18] Emzir; Rohman, Saifur. (2018). TeoridanPengajaran Sastra. Jakarta: PT RajaGrafindo Persada

[19] Pepe, Teresa. (2019). Blogging from Egypt Digital Literature, 2005-2016. United Kingdom: Edinburgh University Press

[20] Ahmad, Bachrudin. (2019). Sastrawan Arab Modern. Jakarta: Guepedia. 
[21] Lesmana,

Maman.

(2019).

Cara PenulisanKaryallmiahUntukTujuanAkademik. Depok: Males Arts Studio

[22] Lenze, Nele. (2019). Politics and Digital Literature in the Middle East Perspective on Online Text and Context. Switxerland: Springer International Publishing

[23] Satinem. (2019). ApresiasiProsaFiksi: Teori, MetodedanPenerapannya. Yogyakarta: Deepublish.

[24] Taufik, Tata. (2020).Dakwah Era Digital.Kuningan: Pustaka AlIkhlash.

[25] Lenze, Nele. (2012). "Telling stories online in the Gulf Prolegomena to the study of an emerging form of Arabic literary expression". Tesis:University of Oslo.

[26] Yusuf, Kamal.

(2013)

"CybersastraSebagaiTemaPenelitiandanPemanfaatanKarya Sastra Arab Online.
[27] FU, Mexing. (2019). "New Wine in Old Bottles: Contemporary Chinese Online Allegorical Ghost Stories as Political Comentary". Jurnal: University Shanghai, Cina. https://annabaa.org/accessed on 15 September 2020

[28] Al-Lawati, Abbas. (2009, Febuari 27). Internet Globalises Arabic Literature. accessed on 2 Oktober 2020 from https://gulfnews.com/entertainment/arts-culture/internetglobalises-arabic-literature-1.53696

[29] Kinnet, Dylan. (2004).The History of and Development of Hypertext and Hypertext Literary Theor. accessed on 12 Oktober 2020 from https://nocategories.net/hypertext/chapter_one.htm\#Inhaltsverzeic hnis 